\title{
Knowledge and Anxiety Levels about the Spread of Covid-19 Cases in the Community in Patihan Village, Madiun City
}

\author{
Vena Agustin Pravitasari1, Riska Ratnawati1 \\ 1) Public Health, Sekolah Tinggi Ilmu Kesehatan Bhakti Husada Mulia Madiun, Indonesia \\ venapravitasari@gmail.com
}

DOI: http://doi.org/10.29080/jhsp.v5i2.592

Received : Agustus 2021, Accepted : Agustus 2021, Published : September 2021

\begin{tabular}{|c|c|}
\hline Keywords & Abstract \\
\hline $\begin{array}{l}\text { Knowledge; } \\
\text { level of anxiety; } \\
\text { Covid-19 }\end{array}$ & $\begin{array}{l}\text { Coronavirus is a disease that can cause respiratory tract infections. The } \\
\text { addition of cases that are increasing every day makes people more worried } \\
\text { about their health. The purpose of this study was to analyze the relationship } \\
\text { between knowledge and the level of anxiety about the spread of Covid-19 cases } \\
\text { in Patihan Village, Madiun City. The researcher used quantitative research with } \\
\text { observational survey method with cross sectional approach. The results of the } \\
\text { bivariate test showed that there was a significant relationship between the } \\
\text { independent variable and the dependent variable, which obtained a value (Sig. } \\
\text { = } 0.034 \text { ) There is a significant relationship between knowledge and the level of } \\
\text { anxiety about the spread of Covid-19 cases in the community in Patihan Village, } \\
\text { Madiun City. The level of knowledge is sufficient to have a moderate level of } \\
\text { anxiety as many as } 5 \text { respondents (55.5\%), the level of knowledge is sufficient } \\
\text { with a level of severe anxiety as many as } 4 \text { respondents (44.5\%), while the level } \\
\text { of knowledge is good with a moderate level of anxiety as many as many as } 4 \\
\text { respondents (17.4\%), and the level of knowledge is good with the level of severe } \\
\text { anxiety as many as } 19 \text { respondents (82.6\%). }\end{array}$ \\
\hline
\end{tabular}

\section{Introduction}

Coronaviruses are a family of viruses that cause disease that can be suffered by humans and animals. If it occurs in humans, it can cause respiratory tract infections, ranging from the common cold to serious diseases such as Middle East Respiratory Syndrome(MERS) and Severe Acute Respiratory Syndrome (SARS). Coronavirus gave rise to a new type of virus found in the human body which first appeared due to an Extraordinary Event (KLB) that appeared in Wuhan, China, in December 2019, then the new type of virus was named Severe Acute Respiratory Syndrome Coronavirus 2 (SARS- Coronavirus). COV2), which causes the disease Coronavirus Disease 2019 (COVID-19) (1). The spread of Covid-19 disease can be infected between humans because someone can be infected from a Covid-19 sufferer. Diseases caused by the Covid-19 virus can spread through small droplets from the nose or mouth of a patient when coughing or sneezing if the patient's nose and mouth are not covered.

The Latest Official Information Media for Emerging Infectious Diseases, the Ministry of Health of the Republic of Indonesia in 2021, stated that the latest situation in the development of Coronavirus Disease 2019 ( Covid-19) was recorded until February 2021 with confirmed cases of 3 countries with the highest confirmed cases globally, the first being the United States with 28,102 confirmed cases. 166 cases followed by India with the number of confirmed cases $11,079,979$ cases in the third place, Brazil with the number of confirmed cases $10,390,461$ (2). Indonesia is one of the countries with the highest confirmed cases at the ASEAN level with the number of confirmed cases of 1,329,074 cases, then in second place is the Philippines with the number of confirmed cases 571,327 cases, the third highest number of confirmed cases is Malaysia, which is 295,951 cases (2).

Provinces in Indonesia with the highest confirmed cases of the spread of Covid-19 in the highest order until the end of February 2021, namely DKI Jakarta Province with 337,637 confirmed cases with 322,207 recovered cases and 5,453 cases who died with a Case Fatality Rate (CFR) of $1,6 \%$. Meanwhile, 
East Java Province is in the position with the fourth highest number of confirmed cases in Indonesia, with 129,135 confirmed cases recorded with 116,245 recovered cases and 9,088 dead cases with a CFR of $7.0 \%$ (2). Madiun City itself is in the 33rd place with the highest confirmed cases in one province of East Java with the number of confirmed cases as many as 1,482 cases with 1,265 cases recovering and 101 cases dying with a CFR of $6.82 \%$ (3). Cases confirmed in the working area of Regional Integrated Service Unit Public Health Center's Patihan as much as 177 confirmed cases and 151 cases cleared and the number of cases who died 7 cases. The fourth sub-district is Patihan Sub-district with 30 confirmed cases with 21 recovered cases with a cure percentage of $70 \%$ and 2 cases dying with a CFR percentage of $6.66 \%$ patihan village election because the increase in confirmed cases is faster than other urban villages (3).

The form of control efforts carried out by the government aims to ensure that the overall strategic plan for preparedness and response for Covid-19 is to control Covid-19 by suppressing virus transmission and preventing disease and death. The Covid-19virus generally spreads from person to person. Understanding how to prevent, what types and places where the spread of SARS-CoV-2 occurs is very important to develop public health measures and infection prevention and control measures to break the chain of transmission (4). Therefore, there is a need for supervision and monitoring from the government which is useful for suppressing the spread of the virus by carrying out restrictions or commonly referred to as PPKM (Enforcement of Restrictions on Community Activities) (5).

The increase in the number of corona cases that occurred in Indonesia occurred in a short time and required immediate treatment. The corona virus can easily spread and infect anyone, the corona virus can be transmitted easily through contact with sufferers. For these reasons the government in some countries decided to lockdown or total isolation or quarantine is done in order to reduce the number of deployment Virus (6). With the lock down, many people experience anxiety due to the COVID-19 pandemic. Anxiety is an action and is also a normal feeling that every human being has anxiety levels are divided into 5 namely there are no axiety, mild anxiety, moderate anxiety, severe anxiety, and panic. The impact of the COVID19 pandemic has made people more aware of the spread and transmission of the coronavirus. Which is where the community must adapt to new habits that are more independent in implementing PHBS (Clean and Healthy Life Behavior). The health protocol implemented during the pandemic is by implementing 5M there are, wearing masks, maintaining distance, washing hands, staying away from crowds, and reducing mobility (5).

Public knowledge about the pandemic makes people more aware of the spread of the virus and how to deal with its spread so that the impact of the COVID-19 pandemic has made people more aware of the spread and transmission of the coronavirus. In which the community must adapt to new habits that are more independent in implementing PHBS such as washing hands with soap and running water for 20 seconds (7). In addition, the public must also interpret the health protocols that have been set by the government as an effort to prevent and overcome the increase in cases. With this research, it is hoped that the community will have a positive impact, such as increasing knowledge about covid-19, ways of preventing and overcoming it, and also always knowing the anxieties that exist in the community during the covid-19 pandemic (8).

\section{Methods}

This type of research is a quantitative research with an observational survey method with a cross sectional approach (9). The independent variable used in this study is knowledge that will affect the dependent variable, namely the level of anxiety. The research instrument used is a validity test and a reliability test. Data analysis used was Kendall's tau- $b$ statistical test with scale data ordinal by ordinal. This research was conducted in the working area of the UPTD Puskesmas Ngegong, precisely in the Patihan Village, Madiun City in July 2021. Kelurahan Patihan consists of 22 RT and 6 RW which are used as the research population. The research sample used was the purposive sampling formula. The number of samples as many as 32 respondents spread with the following formula.

Proportion formula:

$\mathrm{p}=\mathrm{x} / \mathrm{y} \cdot 100 \%$

Is known:

$\mathrm{x}=$ confirmed case $=30$

$\mathrm{y}=1373 \mathrm{KK}$

Formula:

$\mathrm{p}=30 / 173.100 \%$

$\mathrm{p}=0.0218 .100 \%=2.18 \%$ 
Sample formula:

$\begin{array}{ll}\mathrm{n}= & \frac{1373 \cdot(1,96)^{2} \cdot 0,0218 \cdot(1-0,0218)}{(0,05)^{2} \cdot(1373-1)+(1,96)^{2} \cdot 0,0218 \cdot(1-0,0218)} \\ \mathrm{n}= & 112,477 / 3,511 \\ \mathrm{n}= & 32,03 \\ \mathrm{n}= & 32 \mathrm{KK} \text { over every RW in the Patihan Village, Madiun City } .\end{array}$

The data used is secondary data, records of confirmed cases of Covid-19 until the end of February 2021, UPTD Ngegong Health Center. Sample criteria;

1. People who are able to communicate well.

2. The head of the family is willing to be a respondent.

3. Interviews were conducted with substitute respondents (mother/children who were able to answer questions correctly who were members of the sample family), if no head of the family was used as the sample.

4. Stay close to a confirmed Covid-19 person within 10 meters of the confirmed house.

The house used as the research sample is located to the right of the house with confirmed cases. And two samples are located to the left of the confirmed house located in RT 16 RW 5.

\section{Results}

The results of the univariate analysis were carried out to describe the characteristics of the research respondents. Characteristics of respondents can be seen in the table below:

Table 1. Frequency Distribution of Respondents Characteristics

\begin{tabular}{llrr}
\hline \multicolumn{1}{c}{ Characteristics } & \multicolumn{1}{c}{ Categorical } & Frequency & Percentage (\%) \\
\hline Gender & Man & 5 & 15.6 \\
Age & Woman & 27 & 84.4 \\
& 17-25 years Late Adolescence & 5 & 15.6 \\
& 26-35 years Early Adulthood & 4 & 12.5 \\
& 36-45 years Late Adulthood & 9 & 28.1 \\
Work & 46-55 years Early Old Age & 10 & 31.2 \\
& 56-65 years Late Old Age & 4 & 12.5 \\
& Does not work & 5 & 15.6 \\
& Housewife & 14 & 43.8 \\
& Trader & 6 & 18.8 \\
Education & Private employees & 4 & 12.5 \\
& Factory workers & 2 & 6.2 \\
Knowledge & Teacher & 1 & 3.1 \\
& Basic education & 2 & 6.2 \\
Anxiety level & Middle education & 27 & 84.4 \\
& Higher education & 3 & 9.4 \\
Total & Enough knowledge & 5 & 15.6 \\
& Good knowledge & 27 & 84.4 \\
& Moderate anxiety level & 9 & 28.1 \\
& Severe anxiety level & 23 & 71.9 \\
\hline
\end{tabular}

Based on the table above, it can be seen that the majority of respondents in this study were women as many as 27 respondents (84.4\%). The majority of 46-55 years of age are elderly early as 10 respondents (31.2\%). For most of the respondents' work as housewives, 14 respondents (43.8\%). Based on the characteristics of the respondents, the last education of the respondents was secondary education as many as 27 respondents $(84.4 \%)$. The majority of respondents have good knowledge as many as 27 respondents (48.4\%). The anxiety level of the majority of respondents was at the level of severe anxiety as many as 23 respondents (71.9\%).

Based on the research that has been carried out on the community in Patihan Village, the results obtained are:

Table 2. Cross-tabulation between Knowledge and Respondents Anxiety Levels in the Community in Patihan Village, Madiun City

\begin{tabular}{|c|c|c|c|c|c|c|c|}
\hline \multirow{3}{*}{ Knowledge } & \multicolumn{4}{|c|}{ Anxiety Level } & \multirow{2}{*}{\multicolumn{3}{|c|}{ Total }} \\
\hline & \multicolumn{2}{|c|}{ Currently } & \multicolumn{2}{|c|}{ Heavy } & & & \\
\hline & $\mathrm{N}$ & $\%$ & $\mathrm{~N}$ & $\%$ & $\mathbf{N}$ & & $\%$ \\
\hline gh & & 55.55 & 4 & 44.45 & & 9 & 100 \\
\hline & & 17.39 & 19 & 82.61 & & 3 & 100 \\
\hline
\end{tabular}


Based on table 2 shows that the results of the cross tabulation between knowledge and the level of anxiety in respondents, which can be seen that there are sufficient knowledge of 9 respondents consisting of sufficient knowledge of moderate anxiety level as many as 5 respondents (55.55\%), sufficient knowledge of severe anxiety level as much as 4 respondents (44.45\%). For good knowledge there are 23 respondents consisting of good knowledge with moderate anxiety levels as many as 4 respondents (17.39\%) and good knowledge with severe anxiety levels as many as 19 respondents (82.61\%).

Table 3. Statistical tests Kendall's tau-b The Relationship Between Knowledge With Anxiety Levels Against the Spread of Case Covid 19th on the Village People in the City Patihan Madiun

$$
\text { Knowledge Anxiety Level }
$$

\begin{tabular}{|c|c|c|c|c|}
\hline \multirow{6}{*}{ Kendall's tau- $b$} & \multirow{3}{*}{ Respondent Knowledge } & correlation & 1,000 & $0.382^{\prime}$ \\
\hline & & Sig. (2-tailed) & & 0.034 \\
\hline & & $\mathrm{N}$ & 32 & 32 \\
\hline & \multirow{3}{*}{$\begin{array}{l}\text { Respondents Anxiety } \\
\text { Level }\end{array}$} & Corelation & 0.382 & 1,000 \\
\hline & & Sig. (2-tailed) & 0.034 & \\
\hline & & $\mathrm{N}$ & 32 & 32 \\
\hline
\end{tabular}

Based on Table 3 shows the results of statistical tests using test Kendall's tau- $b$ with $\alpha=0.05$. Based on the correlation coefficient, it is obtained a value of 0.382 ' which means a low level of relationship with a positive direction of relationship between the two variables, where knowledge affects the respondent's level of anxiety. The significance value obtained from this study is Sig. $(0,034) \leq$ alpha $(0.05)$. So it can be concluded that accepting $\mathrm{Ha}$ and rejecting $\mathrm{HO}$ which means that there is a positive relationship between knowledge and anxiety levels.

\section{Discussion}

In this sub-chapter, we will discuss the independent variable with the dependent variable (10). The independent variable in this study is knowledge, while the dependent variable in this study is the level of anxiety (8). The Patihan sub-district community who made the majority of respondents were female as many as 27 respondents (84.4\%) with the majority age 46-55 years old as many as 10 respondents (31.2\%) working mostly as housewives as many as 14 respondents (43.8\%), and the most recent education level is secondary education as many as 27 respondents ( $84.4 \%)$. Knowledge is the result of out and this happens after a person perform the sensing of an specific object (11). The respondent's level of knowledge on the level of anxiety is divided into 3 categories, namely good knowledge, sufficient knowledge, and poor knowledge (12).

An increase in one's knowledge is obtained from the results of information (13). If the acceptance of new information or the adoption of information through a process based on knowledge, awareness, and attitude, the information will not cause errors (14). Conversely, if the information is not based on knowledge, awareness will cause errors that will have an impact on fear and also worry or increase anxiety (15).

Anxiety is a psychological condition or individual emotional form (16). In the form of tension, anxiety, concern regarding feelings of being threatened and fear by uncertainty in the future that something bad will happen (17). Anxiety is a feeling of fear that something is caused by the anticipation of danger and is a signal that helps the individual to prepare to take action to face the threat (13). In table 1, 9 respondents (28.1\%) experienced moderate anxiety, 23 respondents (71.9\%). Factors that affect anxiety are potential stressors, maturation or maturity level, education level and economic status, education level, physical condition, personality type, socio-culture, age, gender, environment and situation (18).

From the results of statistical tests Kendall's tau-b obtained significance value of 0, 034 which if Sig $(0,034) \leq$ alpha $(0.05)$ so that the relationship between knowledge and level of anxiety. This can be seen from the frequency distribution of the respondents' anxiety levels, where respondents with moderate anxiety levels were 9 respondents (28.1\%) and severe anxiety levels were 23 respondents (71.9\%). The level of anxiety experienced by respondents is influenced by several factors including knowledge and knowledge influenced by educational factors (19).

The results of this study are supported by research by Gheralyn Regina Suwandi and Evelin Malinti (2020) conducted at Balikpapan Adventist High School which states that as many as 9 respondents (15\%) are knowledgeable enough to experience mild anxiety, 33 respondents (55\%) have good knowledge experience severe anxiety, as many as 4 respondents (6.6\%) with moderate knowledge experienced moderate anxiety, as many as 9 respondents (15\%) with good knowledge experienced moderate anxiety, as 
many as 1 respondent (1.7\%) experienced moderate anxiety, and as many as 4 respondents $(6,7 \%)$ knowledgeable enough to experience severe anxiety. In addition, it is supported by research by Onimus Umbu Daha, Ahmad Guntur Alfianto, MN Lisan Sediawan (2021) conducted on the community in Mojolangu Village, Lowokwaru District, Malang, found 28 respondents with moderate anxiety level with good knowledge level as many as 13 respondents, moderate knowledge 8 respondents, and lack of knowledge as many as 7 respondents. While those who experience severe anxiety are 127 respondents with good knowledge as many as 94 respondents, moderate knowledge as many as 14 respondents, lack of knowledge 14 respondents.

\section{Conclusion}

There is a significant and positive relationship between knowledge and the level of anxiety about the spread of COVID-19 cases in the community in Patihan Village, Madiun City. Suggestions from this study are that it is hoped that the community will be more aware of the transmission of the covid-19 virus by complying with the health protocols set by the government, especially people with comorbid cases and vaccinating against COVID-19. And for further researchers, they can conduct research using a case control design in people who have sufficient level of knowledge and have comorbid factors.

\section{Acknowledgments}

Thanks are conveyed to the Patihan Village, Madiun City and the Public Health Study Program, Bhakti Husada Madiun School of Health Sciences .

\section{References}

1. Kemenkes Ri. Informasi Tentang Virus Corona (Covid-19). Direktorat Promosi Kesehatan Dan Pemberdayaan Masyarakat. 2020.

2. $\quad$ Kemenkes Ri. Situasi Terkini Perkembangan Covid-19. Novel Covid-19. 2021.

3. Dinas Kesehatan Kota Madiun. Info Covid19 Kota Madiun-Kesembuhan Covid 19 Tanggal 28 Februari 2021. Kota Madiun: Kota Madiun Tanggap Covid-19; 2021.

4. World Health Organization (Who). Transmisi Sars-Cov-2: Implikasi Terhadap Kewaspadaan Pencegahan Infeksi. 2020;1-10.

5. Kurniawan I. Hubungan Kecemasan Dengan Kejadian Hipertensi Pada Lansia. Jombang: Sekolah Tinggi Ilmu Kesehatan "Insan Cendekia Medika"; 2018. 31-37 P.

6. Mona N. Konsep Isolasi Dalam Jaringan Sosial Untuk Meminimalisasi Efek Contagious ( Kasus Penyebaran Virus Corona Di Indonesia ) Jurnal Sosial Humaniora Terapan. 2020;2(2):117-25.

7. Nurvaeni Ia. Hubungan Antara Tingkat Kecemasan Dengan Kesiapan Menghadapi Pensiun Pada Guru Sd Di Kecamatan Sentolo Kabupaten Kulon Progo Tahun 2015-2016. Yogyakarta: Universitas Negeri Ypgyakarta; 2016. 11-23 P.

8. Mayasari Af. Hubungan Tingkat Pengetahuan Dengan Tingkat Kecemasan Pada Remaja Awal Dalam Menghadapi Menarche Di Sdn 02 Nambangan Lor Madiun. Madiun: Stikes Bhm Madiun; 2017.

9. Nursalam. Konsep Dan Penerapan Metodologi Penelitian Ilmu Keperawatan. Edisi 2. Tim Editor Salemba Medika, Editor. Jakarta: Salemba Medika; 2008.

10. Nursalam. Metodologi Penelitian Ilmu Keperawatan. Edisi 4. Lestari Pp, Editor. Jakarta: Salemba Medika; 2015.

11. Notoatmodjo S. Ilmu Perilaku Kesehatan. Cetakan Ke. Jakarta: Rineka Cipta; 2010.

12. Notoatmodjo S. Promosi Kesehatan Dan Perilaku Kesehatan. Jakarta: Rineka Cipta; 2011.

13. Healthy Saventina Sirait, Awis Hamid Dani Drm. Hubungan Pengetahuan Tentang Covid-19 Terhadap Tingkat Kecemasan Pada Lansia Yang Mengalami Hipertensi. J Kesehat. 2020;11(2):165-9.

14. Arikunto S. Prosedur Penelitian : Suatu Pendekatan Praktik. Jakarta: Rineka Cipta; 2013.

15. Gheralyn Regina Suwandi Em. Hubungan Tingkat Pengetahuan Dengan Tingkat Kecemasan Terhadap Covid19 Pada Remaja Di Sma Advent Balikpapan. Malahayati Nurs J. 2020;2(4):677-85.

16. Prambudi As. Hubungan Karakteristik Penduduk Dengan Perilaku Buang Air Besar Sembarangan (Babs) Di Desa Kenongorejo Kecamatan Pilangkenceng Kabupaten Madiun. Skripsi. Prambudi As, Editor. Madiun: Stikes Bhm Madiun; 2019. 48-56 P.

17. Tambaru R. Pengaruh Kecemasan Pandemi Covid-19 Terhadap Pengeluaran Asi Ibu Post Partum Di Bidan Praktik Mandiri Hj. Rusmawati Di Muara Badak. Muara Badak Kalimantan Timur; 2020. 37-56 P.

18. Notoatmodjo S. Metodologi Penelitian Kesehatan. Edisi Revi. Jakarta: Rineka Cipta; 2012.

19. Sugiyono Pd. Metode Penelitian Kuantitatif, Kualitatif, Dan R\&D. Bandung: Alfabeta; 2013. 